\title{
The Acceptance and Use of an Online Exam System by Online Learners: Implementation of the UTAUT Model*
}

\author{
Gülgün AFACAN ADANIR ${ }^{* *}$
}

\author{
Murat ÇINAR $^{* * *}$
}

\begin{abstract}
The achievement of technology depends heavily on its actual use by the target users. Similarly, the success of online exam systems also depends on the acceptance of target learners. In this regard, the purpose of this study was to investigate the factors that affect the acceptance of an online exam system by online learners. The study was conducted at a state university in Turkey during the fall semester of 2019-2020. A total of 277 online learners participated in this study. The research model of the study was based on the Unified Theory of Acceptance and Use of Technology (UTAUT). Participants' data were collected through a survey, which included items of performance expectancy, effort expectancy, facilitating conditions, and social influence factors from the UTAUT model. Structural equation modelling (SEM) analysis was used to investigate the structure of the research model. The SEM results revealed that performance expectancy and facilitating conditions were positively related to online learners' acceptance of an online exam system. However, according to the results, effort expectancy and social influence were not significantly related to online learners' acceptance of an online exam system.
\end{abstract}

Keywords: Online exam system, online learner, acceptance, UTAUT.

\footnotetext{
* The ethics committee approval for this study was obtained from the Ethics Committee of the Rectorate of Ankara University, dated 07/10/2019 and numbered 12/357.

** Orcid ID: https://orcid.org/0000-0002-0832-1808, Dr., Ankara University, Turkey, gulgunafacan@gmail.com

*** Orcid ID: https://orcid.org/0000-0002-2293-706X, Lect., Ankara University, Turkey, mcinar@ankara.edu.tr 


\section{INTRODUCTION}

Online exams are considered as a suitable tool for assessing learners' knowledge using information technology, while not requiring pencil and paper as with traditional exams (Sarrayrih \& Ilyas, 2013). Every day, an increasing number of universities around the world are using online exams. Especially, online programs have begun more and more to offer online exams for target learners. Online exams offer several advantages for learning and teaching. First, it adds flexibility so that students can access exams online at a convenient time and place. Online exams shorten the exam time for students and the time it takes to post their scores. Also, test administration becomes efficient, especially for classes with a large number of students. The grading process can be automated and made more objective through the online exam features (Karaman, 2011).

As a developing country, Turkey has also begun adopting online exams. In addition to institutional exams such as driving license exams and job promotion exams, Turkish universities have started to adopt online exams as an assessment method for both online and face-to-face courses (Ilgaz \& Adanır, 2020). User acceptance is critical for the successful implementation of any new technology (Taherdoost, 2019). To date, several studies have been conducted to better understand the determinants of information technology use in various fields (Granić \& Marangunić, 2019). In this respect, researchers have applied different theoretical models to reveal user intentions and behavior related to use of information technologies. Common models are the Technology Acceptance Model (TAM) (Davis, 1989), Diffusion of Innovation Model (Rogers, 1995), and Unified Theory of Acceptance and Use of Technology (Venkatesh, Morris, Davis, \& Davis, 2003). Existing studies on online exam acceptance (e.g., Maqableh, Masa'deh, \& Mohammed, 2015; Terzis \& Economides, 2011) also consider these three as core models according to their methodologies.

\section{Unified Theory of Acceptance and Use of Technology (UTAUT)}

UTAUT is based on existing technology acceptance frameworks. UTAUT contains key components of previously developed acceptance models (Venkatesh et al., 2003). Overall, UTAUT includes four major factors: performance expectancy, effort expectancy, social influence, and facilitating conditions (Figure 1). 


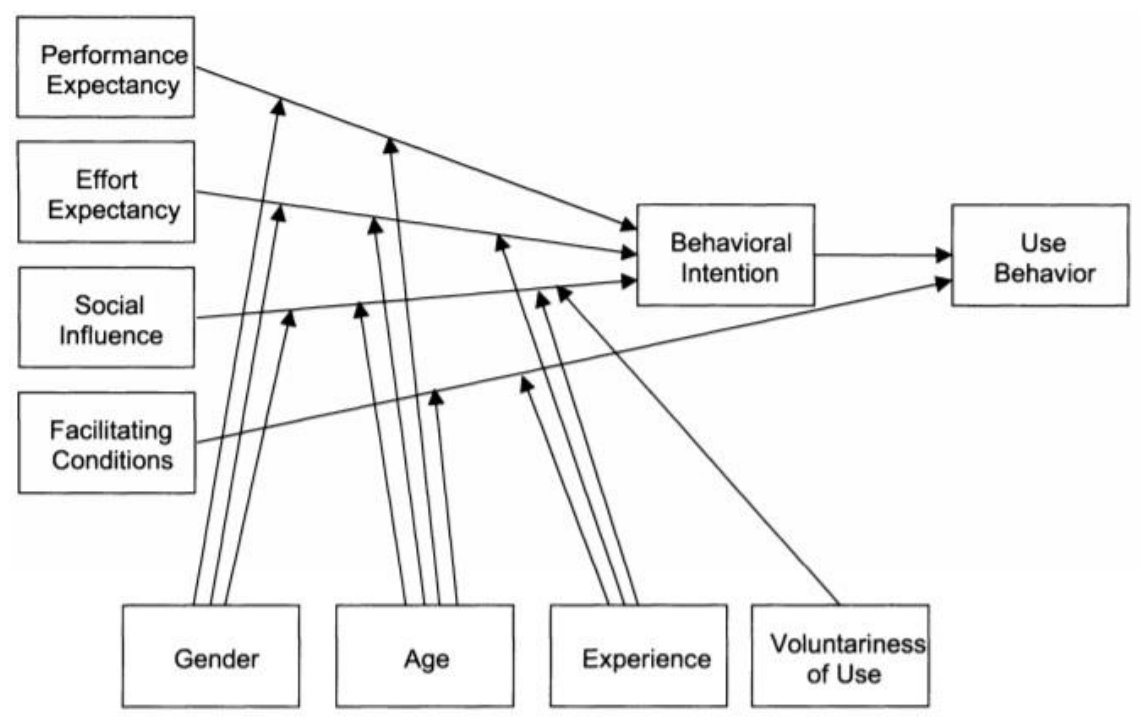

Figure 1. Structure of UTAUT

Performance expectancy is defined as "the degree to which an individual believes that using the system will help him or her to attain gains in job performance" (Venkatesh et al., 2003, p. 447). Effort expectancy is defined as "the degree of ease associated with the use of the system" (Venkatesh et al., 2003, p. 450). Social influence is defined as "the degree to which an individual perceives that important others believe he or she should use the new system" (Venkatesh et al., 2003, p. 451). Facilitating conditions are defined as "the degree to which an individual believes that an organizational and technical infrastructure exists to support use of the system" (Venkatesh et al., 2003, p. 453). In addition, UTAUT includes four moderators (i.e., gender, age, experience, voluntariness of use) that mediate the effects of four major determinants regarding users' behavioral intention to use a technology.

\section{Learners' Perceptions and Acceptance Related to Online Exams}

To date, learners' perceptions related to online exams have been investigated in several studies. It is found in these studies that learners generally report positive comments about online exams (Al-Mashaqbeh \& Al Hamad, 2010; Hillier, 2014). For instance, Dermo (2009) proposes a tool for examining learners' perceptions of e-assessment according to factors related to validity, reliability, security, learning, and teaching. It is revealed in Dermo (2009) that learners generally exhibit positive behaviors according to each factor. On the other hand, they are concerned about the fairness of the exams because they consist of random questions, each with different degrees of difficulty. In his study, which investigates preconceptions towards e-exams, Hillier (2014) finds that in general students have positive attitudes regarding the implementation of e-exams, but are concerned with the possibility of technical failures and cheating.

Cabı (2016) analyzes students' perceptions of different e-assessment methods. It is revealed in her study that students prefer e-exams because of the characteristics of 
immediate feedback, motivation to learn, and self-assessment. Yet, student concerns are related to the possibility of cheating and technical failures as well as the lack of exam sessions during the semester. Alsadoon (2017) examines students' perceptions towards e-assessment in Saudi Electronic University and finds that students appraise the immediate feedback, unbiased grading, and enhanced self-learning aspects of electronic exams.

Afacan Adanır, İsmailova, Omuraliev and Muhametjanova (2020) investigate students' perceptions of online exams at two different universities. In their study, students report that online exams are less stressful and more reliable than traditional paper-based exams. In Terzis and Economides (2011) they develop a model to investigate learners' behavioral intention to use computer-based assessment. Their model, the Computer Based Assessment Acceptance Model (CBAAM), is based on TAM, the Theory of Planned Behavior (TPB), and the UTAUT. Their study explores if perceived ease of use and perceived playfulness are found to have direct impacts on learners' acceptance of computer based assessment. In addition, perceived usefulness, computer self-efficacy, social influence, facilitating conditions, content, and goal expectancy are found to have indirect impacts on learners' acceptance of computer based assessment.

The CBAAM is also applied to identify differences between cultures regarding student acceptance of computer-based assessment (Terzis, Moridis, Economides, \& Mendez, 2013). It is shown in one study, that Greek students' behavioral intentions to use computer-based assessment are influenced by perceived playfulness and perceived ease of use factors, while Mexican students' behavioral intentions are influenced by perceived playfulness and perceived usefulness factors (Terzis et al., 2013).

Based on the UTAUT, Tan (2013) examines university learners' attitudes and expectations related to e-placement tests, which are primarily used to identify learners' skills, ability or knowledge. It is found in the study that performance expectancy, effort expectancy, and social influence factors have a significant impact on learners' behavioral intention to use e-placement tests. On the other hand, it is revealed in the study that the facilitating conditions factor has no significant impact on learners' use of e-placement tests.

Furthermore, Maqableh, Masa'deh and Mohammed (2015) propose a new model based on the TAM, TPB, and UTAUT models, which is aimed at analyzing the acceptance of computer based assessment by university students. It is demonstrated in the results of the study that perceived playfulness, which refers to the system's capability to hold learners' concentration, curiosity, and enjoyment, does have a significant effect on students' acceptance of computer based assessment. Besides, perceived ease of use, perceived usefulness, computer self-efficacy, social influence, facilitating conditions, content, and goal expectancy factors are also found to have indirect effects on students' acceptance of computer based assessment. Okocha, Eyiolorunshe and Olowabi (2017) investigate Nigerian students' perceptions and acceptance of computer based testing. It 
is revealed in their study that most of the students have positive attitudes towards computer based testing.

Although there have been some previous studies (e.g., Afacan Adanir et al., 2020; Cabi, 2016; Dermo, 2009; Hillier, 2014) that investigate learners' perceptions towards online exams, there is a limited number of studies which investigate the factors affecting acceptance of online exams (Zheng \& Bender, 2018). As seen in all innovative technologies, there can be difficulties related to acceptance of online exams by learners. In addition, the success of online exams is highly dependent on student acceptance (Terzis \& Economides, 2011).

In the context of this study, online exam systems were recently initiated in one of the state universities in Turkey. In this regard, it was important to identify Turkish learners' acceptance of online exam systems. Hence, the aim of this study was to investigate acceptance of an online exam system by Turkish learners._This study will add to the existing literature by providing empirical results regarding factors which determine student acceptance of online exam systems. In addition, this study investigated Turkish students' acceptance of an online exam system. In this respect, the current study will be among this initial type of study in the literature.

\section{METHOD}

\section{Research Model and Hypotheses}

The UTAUT is commonly employed to investigate the acceptance of information technologies (Arpaci, 2015). Similarly, it was demonstrated through a review of the literature, that the UTAUT is often the preferred model in existing studies (Maqableh, Masa'deh, \& Mohammed, 2015; Tan, 2013; Terzis \& Economides, 2011; Terzis et al., 2013) which examine the acceptance of online exams. The UTAUT is identified as a significant model because it is based on prior models employed to determine users' acceptance of information technologies (Maphosa, Dube, \& Jita, 2020). Therefore, the UTAUT was found to be the appropriate model in this current study for investigating online learners' acceptance of an online exam system. The structure of the research model is demonstrated in Figure 2. 


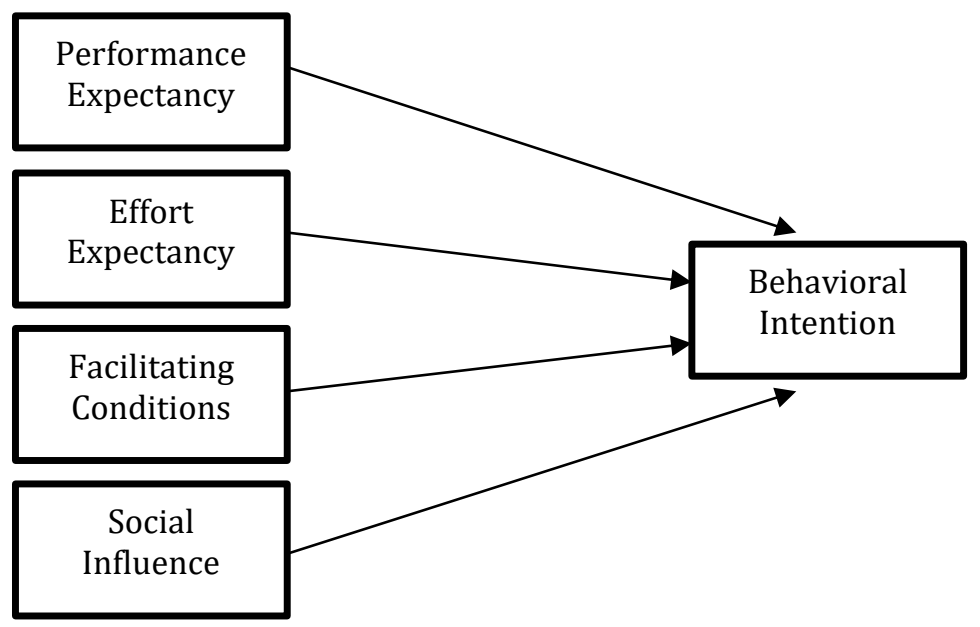

Figure 2. Structure of the Research Model

The dimensions of the proposed research model and the corresponding hypotheses were as follows:

Performance Expectancy refers to individuals' beliefs that an information system will allow them to gain advantages in job performance. In the context of online exam systems, performance expectancy refers to the increase in academic performance and time savings during the exam. If learners understand these advantages of online exam systems, they will have more intention to use such systems. Therefore, the relevant hypothesis was formulated as follows:

H1: Performance expectancy has a significant positive effect on learners' behavioral intention to use an online exam system.

Effort Expectancy is the level of ease with which technology is used. It is important that learners understand the use of online exam systems as well as demonstrate the necessary skills when using the system. Thus, easy-to-use features in online exam systems increase learners' intention to use these systems. In this regard, the following hypothesis was generated:

H2: Effort expectancy has a significant positive effect on learners' behavioral intention to use an online exam system.

Facilitating conditions include individuals' beliefs that organizational and technical infrastructure exists to support the use of a technology. When using online exam systems, the required technology (such as computer, internet connection), necessary knowledge, and technical support are taken into consideration. If the necessary facilitation conditions are present, the use by learners of online exam systems will increase. In this respect, the following hypothesis was considered: 
H3: Facilitating conditions have significant positive effect on learners' behavioral intention to use an online exam system.

Social Influence refers to the impact of people on the adoption of a technology by individuals. In the context of online exams, learners can be influenced by the ideas of instructors and/or peers when using online exam systems. In addition, university support and facilities motivate learners to use online exam systems. The corresponding hypothesis was stated as follows:

H4: Social influence has a significant positive effect on learners' behavioral intention to use an online exam system.

\section{Research Setting}

The current study was conducted at a state university in Turkey during the 2019-2020 fall term. This study was aimed at investigating online learners' acceptance of the online exam system developed within the Moodle Learning Management System (LMS). The online exam system was used by the university for the implementation of exams through online means. The target users of the online exam system were online learners studying at the two-year vocational education level and the instructors teaching courses at that level. Online learners could complete midterm and final exams using the online exam system. However, instructors could expect students to submit assignments instead of taking midterm exams. Thus, by using the online exam system, instructors initially created question banks and prepared online tests for the courses they taught. Then, online learners were informed about the exam schedule via LMS forums, social media platforms, and SMS. During the exam days, online learners logged into the system and took their course exams online from various locations, such as home, the computer laboratory or library. While online exams were taking place, an online chat team was available to meet the urgent needs of learners. This meant that in the event of a temporary internet or power outage, learners would use the chat feature to apply to the team for gaining additional rights to rejoin the exam. After the online exams, learners could access the system to learn their grades as well as their correct and incorrect answers. In addition, the instructors could learn the grades of learners by using the online exam system.

\section{Research Design and Participants}

This study was aimed at explaining the structural equation model based on the UTAUT, regarding online learners' performance expectancy, effort expectancy, facilitating conditions, and social influence factors affecting behavioral intention to use the online exam system. In the present study, correlational research design was used to analyze the casual relationship between factors in the theoretical model. That is, the factors were taken as independent variables and the behavioral intention was taken as the dependent variable.

Purposive sampling method was applied to identify the participants of the study. Purposive sampling method is found appropriate for gathering data from particular 
individuals or events which are selected intentionally (Taherdoost, 2016). In the context of this study, online learners studying at the vocational level were considered, and there was no age restriction for participants.

After the online exams, the data of participant learners were collected through an online survey integrated into the LMS. First, online learners were informed about the study, and then volunteer participants provided responses to the survey questions. Demographic profiles of participants are provided in Table 1.

Table 1

Demographic Profiles of Learners

\begin{tabular}{llcc}
\hline & Items & Frequency & Percentage (\%) \\
\hline Gender & Male & 105 & 37.9 \\
& Female & 172 & 62.1 \\
\hline Department & BAI & 89 & 32.1 \\
& CP & 23 & 8.3 \\
& EDM & 31 & 11.2 \\
& JDSP & 21 & 7.6 \\
& LOMS & 42 & 15.2 \\
& MDSP & 34 & 12.3 \\
& THM & 37 & 13.4 \\
\hline Total & & 277 & 100 \\
\hline
\end{tabular}

A total of 277 online learners participated in this study. Participants studied in seven different online programs at the vocational level. These programs were Banking and Insurance (BAI), Computer Programming (CP), Emergency and Disaster Management (EDM), Judicial Services Support Personnel (JDSP), Law Office Management Secretary (LOMS), Medical Documentation Support Personnel (MDSP), and Tourism and Hotel Management (THM).

\section{Data Collection and Analysis}

The survey was adapted from scales based on the UTAUT model from Venkatesh et al. (2003) and covered the items of performance expectancy, effort expectancy, social influence, and facilitating conditions factors. The survey items are provided in AppendixA.

The survey was translated to Turkish and provided in an online environment to receive responses from the participants. To confirm the suitability of the survey items for the evaluation of the intended contents, the content validity of the items was carried out. Judgements were obtained from two different experts who reviewed and revised all the 
survey items. One of the experts specialized in online learning, especially in online exams, and the other expert specialized in assessment and evaluation within education.

The analysis consisted of reliability analysis, confirmatory factor analysis (CFA), convergent validity, discriminant validity, model-fit testing, and Structural Equation Modelling (SEM). Reliability analysis was conducted to test the consistency of the factors with the hypothesized results. The purpose of the CFA was to determine whether the items defined by the study were correctly loaded into the relevant factors. Convergent and discriminant validity were identified as subcategories of the construct validity. The purpose of convergent validity is to check that the measures which should be related are actually related. Discriminant validity is intended to show that measures that should not be related are not really related (Trochim, n.d.). The model-fit testing was conducted to validate the structure of the model. While SEM analysis was applied to investigate the structure of the research model. The findings related to these analyses are provided in the Findings section.

\section{FINDINGS}

Reliability analysis was performed to determine whether the factors were in line with hypothesized results. The information in Table 2 demonstrates that the Cronbach's Alpha values resulting for factors were between 0.885 and 0.952 . Therefore, each value was found to exceed the suggested level of 0.70 (Kline, 1999), as a result, they were suitable for reliability.

Table 2

Reliability Analysis Results

\begin{tabular}{ll}
\hline & Cronbach's Alpha \\
\hline Performance Expectancy (PE) & 0.944 \\
Effort Expectancy (EE) & 0.944 \\
Social Influence (SI) & 0.885 \\
Facilitating Conditions (FC) & 0.911 \\
Behavioral Intention (BI) & 0.952 \\
\hline
\end{tabular}

CFA was conducted and the standardized regression weights are provided in Table 3. 
Table 3

Standardized Regression Weights

\begin{tabular}{|c|c|c|}
\hline Item \# & Item & Estimate \\
\hline PE1 & I would find the online exam system useful. & .878 \\
\hline PE2 & $\begin{array}{l}\text { Using the online exam system enables me to solve questions more } \\
\text { quickly. }\end{array}$ & .865 \\
\hline PE3 & Using the online exam system increases my productivity. & .945 \\
\hline PE4 & $\begin{array}{l}\text { If I use the online exam system, I will increase my academic } \\
\text { achievement. }\end{array}$ & .907 \\
\hline EE1 & $\begin{array}{l}\text { My interaction with the online exam system would be clear and } \\
\text { understandable. }\end{array}$ & .827 \\
\hline EE2 & $\begin{array}{l}\text { It would be easy for me to become skillful at using the online exam } \\
\text { system. }\end{array}$ & .945 \\
\hline EE3 & I would find the online exam system easy to use. & .923 \\
\hline EE4 & Learning to operate the online exam system is easy for me. & .915 \\
\hline SI1 & $\begin{array}{l}\text { People who influence my behavior think that I should use the online } \\
\text { exam system. }\end{array}$ & .965 \\
\hline $\mathrm{SI} 2$ & $\begin{array}{l}\text { People who are important to me think that I should use the online } \\
\text { exam system. }\end{array}$ & .970 \\
\hline SI3 & My university has been helpful in the use of the online exam system. & .579 \\
\hline SI4 & $\begin{array}{l}\text { In general, my university has supported the use of the online exam } \\
\text { system. }\end{array}$ & .606 \\
\hline FC1 & $\begin{array}{l}\text { I have the resources (computer, Internet connection) necessary to use } \\
\text { the online exam system. }\end{array}$ & .876 \\
\hline FC2 & I have the knowledge necessary to use the online exam system. & .952 \\
\hline FC3 & $\begin{array}{l}\text { The online exam system is not compatible with other learning systems } \\
\text { I use. }\end{array}$ & -.035 \\
\hline FC4 & $\begin{array}{l}\text { A specific person (or group) is available for assistance with online } \\
\text { exam system difficulties. }\end{array}$ & .462 \\
\hline BI1 & I intend to use the online exam system in the next terms. & .953 \\
\hline $\mathrm{BI} 2$ & I predict I would use the online exam system in the next terms. & .936 \\
\hline $\mathrm{BI} 3$ & I plan to use the system in the online exam system in the next terms. & .908 \\
\hline
\end{tabular}


According to the results in Table 3, four items (i.e., SI3, SI4, FC3, and FC4) were removed from the model because their estimated regression weights were less than 0.7 (Hair, Black, Babin, \& Anderson, 2010).

\section{Convergent Validity}

Convergent validity aims to check that the measures that should be related are actually related (Trochim, n.d.). Convergent validity was checked according to value of average variance extracted (AVE). The corresponding results are provided in Table 4. The AVE value for each factor was greater than 0.5 , confirming the significance of convergence (Fornell \& Larcker, 1981).

Table 4

Results for the Convergent Validity and Discriminant Validity

\begin{tabular}{llllll}
\hline AVE & Construct & PE & EE & SI & FC \\
\hline 0.808 & PE & $\mathbf{0 . 8 9 9}$ & & & \\
0.816 & EE & 0.814 & $\mathbf{0 . 9 0 3}$ & & \\
0.936 & SI & 0.730 & 0.532 & $\mathbf{0 . 9 6 7}$ & \\
0.836 & FC & 0.661 & 0.879 & 0.424 & $\mathbf{0 . 9 1 4}$ \\
\hline
\end{tabular}

\section{Discriminant validity}

Discriminant validity is intended to show that measures that should not be related are not actually related (Trochim, n.d.). The test of Fornell and Larcker (1981) was applied to check discriminant validity in this study. Discriminant validity is confirmed when the square root of the AVE of a construct is greater than its each correlation with other constructs (Fornell \& Larcker, 1981). In Table 4, the diagonal elements represent the square root of AVEs. All of the square roots of AVEs were higher than any other correlation. Therefore, the discriminant validity of the proposed research model was confirmed.

\section{The Model-Fit Testing}

A model fit analysis was performed to validate the structure of the model. The results of the model fit are shown in Table 5. 
Table 5.

Model Fit Results

\begin{tabular}{ll}
\hline Fit Indices & Values \\
\hline $\mathrm{X}^{2} / \mathrm{df}$ & 3.347 \\
$\mathrm{CFI}$ & 0.965 \\
$\mathrm{GFI}$ & 0.887 \\
RMSEA & 0.092 \\
\hline
\end{tabular}

As can be seen from Table $5, \mathrm{X}^{2} / \mathrm{df}$ value was very close to 3 and less than 5 , which indicated the goodness of the model fit (Sümer, 2000). In addition, CFI and GFI values close to 1 and RMSEA values close to 0 were recommended for model fit (Schumacker \& Lomax, 2010). In the results of the study, the CFI value was found to be 0.965 and the GFI value to be 0.887 , which were close to the value of 1 . According to the results of the study, the RMSEA value was 0.092 and was found to be close to 0 . As a result, the fit criteria values confirmed the model fit.

\section{Testing Hypotheses}

In AMOS (v.20), SEM analysis was applied to investigate the structure of the model. The results of the SEM analysis are demonstrated in Table 6 and Figure 3.

Table 6

Results of the SEM Analysis

\begin{tabular}{lcccc}
\hline Path & Estimate & S.E. & C.R. & P \\
\hline Performance Expectancy-Behavioral Intention & .585 & .111 & 5.276 & $* * *$ \\
Effort Expectancy-Behavioral Intention & .056 & .154 & .362 & .718 \\
Facilitating Conditions-Behavioral Intention & .348 & .113 & 3.083 & .002 \\
Social Influence-Behavioral Intention & .060 & .059 & 1.019 & .308 \\
\hline
\end{tabular}

It was revealed in the SEM results that performance expectancy $(\beta=.111, \mathrm{CR}=5.276, \mathrm{p}$ $<.001)$ and facilitating conditions $(\beta=.113, \mathrm{CR}=3.083, \mathrm{p}<.05)$ were positively related to online learners' behavioral intention to use an online exam system. However, effort expectancy $(\beta=.154, C R=.362, p=.718)$ and social influence $(\beta=.059, C R=1.019, p=$ .308) were not significantly related to online learners' behavioral intention to use an online exam system. 


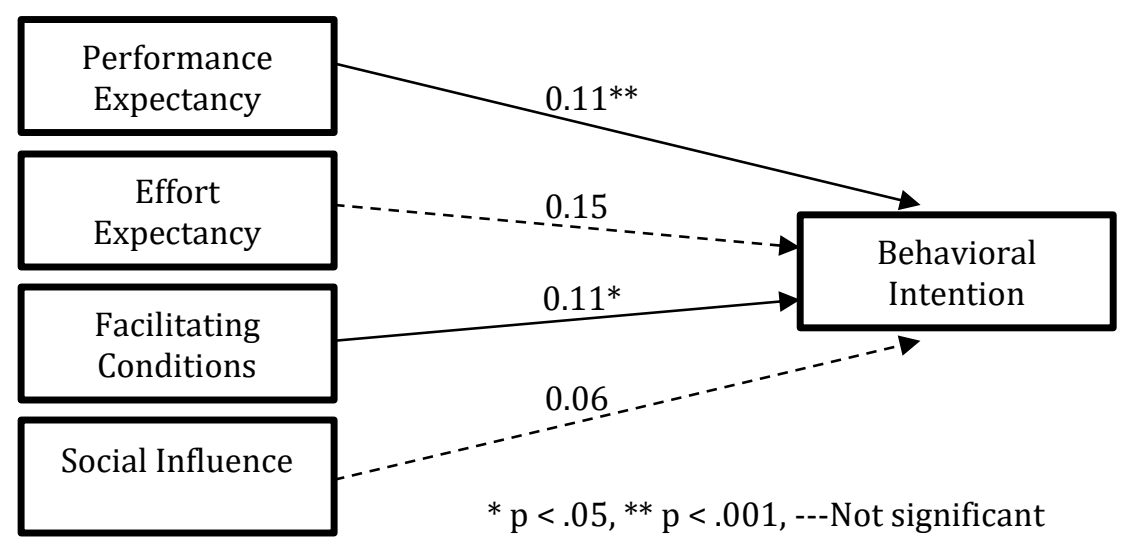

Figure 3. The Structural Model with Results

\section{RESULTS, DISCUSSIONS AND SUGGESTIONS}

The purpose of this study was to examine the acceptance of an online exam system by online learners. It was demonstrated in the results of this current study that learners' performance expectancies significantly affected their behavioral intention to use an online exam system. Similar results have also been explored in prior studies that investigate the acceptance of online exams by learners. For instance, Tan (2013) finds that performance expectancy significantly affected learners' acceptance of e-placement tests. In addition, Terzis et al. (2013) find that perceived usefulness has a significant impact on learners' acceptance of computer based assessment. As one of the components of TAM, perceived usefulness includes the users' beliefs that use of specific systems improves work performance. In this respect, the perceived usefulness factor of TAM demonstrates a great similarity between the performance expectancy factors of UTAUT. In a recent study, Karaoğlan Yılmaz, Yılmaz and Öztürk (2020) investigate students' acceptance of a web-based formative assessment system. Similar to the present study, their study (e.g., Karaoğlan Yılmaz, Yılmaz, \& Öztürk, 2020) reveals a significant effect of perceived usefulness on students' acceptance of the system.

Based on the performance expectancy factor, online learners reported that they solve questions faster when using the online exam system. This implied that use of the online exam system allowed learners to read and answer questions for an appropriate amount of time compared to the paper-based system. This result was parallel to the results of Jawaid et al. (2014), which find that learners allocate less time to complete online tests. However, according to Ilgaz and Adanır (2020), online exams may take longer to solve because they can involve questions which require mathematical calculations. Therefore, online exams should be properly planned as well as learners should be allotted the appropriate time to complete exams. 
At the same time, online learners stated that online exam systems resulted in more productivity in terms of the exam process. This finding was similar with the results of prior studies, for instance, in Zheng and Bender (2018), learners indicate that online exams provide timely and rich feedback regarding their examination performance. That is, learners can receive instant feedback after solving questions through online selfassessment tests. In this way, learners can quickly identify their correct and incorrect answers. In addition, learners can immediately check their grades after completing the online exam, so that they do not have to wait an extended amount of time.

According to the results of the current study, learners believed that they could improve their academic performance by using online exam systems. Similar results have also been explored in prior studies, for instance, Al Salmi, Al-Majeed and Karam (2019) find that online assessment facilitates the instruction process as well as results in higher achievement among learners. Especially, online self-assessment tests allow students to identify their level of understanding (Ibabe \& Jauregizar, 2010). After taking online selfassessment tests, students can detect their level of prior knowledge or can assess their understanding and performance following the course. Moreover, self-assessment results may direct learners to further study subjects in which they have some lack of understanding. In this way, learners can have an opportunity to read or practice in these subject areas, so that they can increase their overall course achievement.

In the current study, it was found that facilitating conditions had a significant influence on the learners' behavioral intention to use an online exam system. Similar results were also observed in the literature, for example, Maqableh, Masa'deh and Mohammed (2015) reveal that facilitating conditions have a positive and direct effect on learners' intentions to use computer based exams. With regards to the facilitating conditions factor, learners indicate that their use of an online exam system increases when they have the necessary knowledge to use the system and the necessary technical resources such as computer and Internet connection. This is important because in the case of technical failures, learners can experience difficulties in accessing online exam systems, therefore become stressed (Cabi, 2016). For the successful implementation of an online exam system, there must be appropriate guides related to the use of the system as well as an adequate technical infrastructure in place.

According to the effort expectancy factor, users believe that using an online exam system would not require effort. In this study, it was found that learners' effort expectancies did not influence their behavioral intention to use the online exam system. This implied that the ease of online exam systems had no effect on participant learners' usage. The usage of the online exam system was very similar to the usage of the learning management system, which had been commonly used by participant learners. Since students were accustomed to using the system, this factor may not have had a significant effect on their acceptance of an online exam system. However, this result is not consistent with the results of several prior studies. For instance, Tan (2013) finds a significant effect of effort expectancy on behavioral intention to use e-placement tests. Similarly, Zheng and 
Bender (2018) find a significant effect of perceived ease of use on learners' behavioral intention to use computer based assessment.

Social influence factor indicates that users shape their behaviors according to thoughts of people important to them. In this study, the social influence factor was not found to have a significant influence on learners' behavioral intention to use an online exam system. The results of the current study were logical because learners were required to use this system in the context of their courses and their intentions were not influenced by other people (i.e., peers, friends, family). On the other hand, the opposite findings are found in previous studies. For instance, Sriyeni, Antoni and Akbar (2018) find a significant effect of social influence on students' acceptance of computer based tests.

The primary focus of the current study was to investigate the factors which affect the acceptance of an online exam system. This study was conducted at a state university in Turkey during the fall semester of 2019-2020. A total of 277 online learners participated in the study. The research model was based on the UTAUT, and included the factors of performance expectancy, effort expectancy, facilitating conditions, and social influence. SEM analysis was used to investigate the structure of the research model. As a result, it was revealed through the SEM findings, that performance expectancy and facilitating conditions were positively related to online learners' acceptance of an online exam system. However, according to these results, effort expectancy and social influence were not significantly related to online learners' acceptance of an online exam system.

There were limitations of sample size in this study. The number of learners who answered the questionnaire was not as high as expected. Approximately, $30 \%$ of the available online learners participated in this study. As a result, in future studies it would be beneficial to collect data from a larger sample.

Another limitation of this study was that the survey was used as a data collection method. In future studies, one-on-one interviews can be conducted with learners to learn more about their use of online exam systems. At the same time, qualitative analysis can be applied to carry out a more detailed investigation of learners' acceptance of such systems. Therefore, it can be possible to better identify reasons for the impact of factors on the acceptance of online exam systems. The final limitation was that only online learners were considered in this study. Thus, in future studies, the acceptance of online exam systems by the learners registered in face-to-face programs can also be investigated. 


\section{References}

Afacan Adanır, G., İsmailova, R., Omuraliev, A., \& Muhametjanova, G. (2020). Learners' perceptions of online exams: A comparative study in Turkey and Kyrgyzstan. International Review of Research in Open and Distributed Learning, 21(3), 1-17. doi: 10.19173/irrodl.v21i3.4679

Al-Mashaqbeh, I. F., \& Al Hamad, A. (2010). Student's perception of an online exam within the Decision Support System Course at Al al Bayt University. In Proceedings Second International Conference on Computer Research and Development, ICCRD 2010 (pp. 131-135). IEEE, https://ieeexplore.ieee.org/document/5489480

Alsadoon, H. (2017). Students' perceptions of e-assessment at Saudi Electronic University. Turkish Online Journal of Educational Technology-TOJET, 16(1), 147-153. Retrieved from: https://files.eric.ed.gov/fulltext/EJ1124924.pdf

Al Salmi, S., Al-Majeed, S., \& Karam, J. (2019). Online exams for better students' performance. In: Proceedings of the 9th International Conference on Education, Teaching \& Learning (ICE19New York Conference). Globalbizresearch, http://eprints.glos.ac.uk/6803/

Arpaci, I. (2015). A comparative study of the effects of cultural differences on the adoption of mobile learning. British Journal of Educational Technology, 46(4), 699-712. doi: 10.1111/bjet.12160

Cabı, E. (2016). Uzaktan eğitimde e-değerlendirme üzerine öğrenci algıları [The perception of students on e-assessment in distance education]. Journal of Higher Education \& Science/Yüksekögretim ve Bilim Dergisi, 6(1), 94-101. doi:10.5961/jhes.2016.146.

Davis, F. D., (1989). Perceived usefulness, perceived ease of use and use acceptance of information technology. MIS Quarterly, 13(3), 319-339. doi: 10.2307/249008

Dermo, J. (2009). e-Assessment and the student learning experience: A survey of student perceptions of e-assessment. British Journal of Educational Technology, 40(2), 203214. doi: 10.1111/j.1467-8535.2008.00915.x

Fornell, C., \& Larcker, D. F. (1981). Evaluating structural equation models with unobservable variables and measurement error. Journal of Marketing Research, 18(1), 39-50. doi: $10.1177 / 002224378101800104$

Granić, A., \& Marangunić, N. (2019). Technology acceptance model in educational context: A systematic literature review. British Journal of Educational Technology, 50(5), 25722593. doi: $10.1111 /$ bjet.12864

Hair, J. F., Black, W. C., Babin, B. J., \& Anderson, R. E. (2010). Multivariate data analysis. New York: Pearson.

Hillier, M. (2014). The very idea of e-Exams: Student (pre) conceptions. In B. Hegarty, J. McDonald, \& S.-K. Lok (Eds.), Rhetoric and Reality: Critical perspectives on educational technology. Proceedings of the Australasian Society for Computers in Learning in Tertiary Education (Ascilite). (pp.77-88). Retrieved from https://ascilite.org/conferences/dunedin2014/files/fullpapers/91-Hillier.pdf

Ibabe, I., \& Jauregizar, J. (2010). Online self-assessment with feedback and metacognitive knowledge. Higher Education, 59(2), 243-258. doi: 10.1007/s10734-009-9245-6 
Ilgaz, H., \& Adanır, G. A. (2020). Providing online exams for online learners: Does it really matter for them?. Education and Information Technologies, 25(2), 1255-1269. doi: 10.1007/s10639-019-10020-6

Jawaid, M., Moosa, F. A., Jaleel, F., \& Ashraf, J. (2014). Computer based assessment (CBA): Perception of residents at Dow University of Health Sciences. Pakistan Journal of Medical Sciences, 30(4), 688-691. doi: 10.12669/pjms.304.5444.

Karaman, S. (2011). Examining the effects of flexible online exams on students' engagement in e-learning. Educational Research and Reviews, 6(3), 259-264. doi: 10.5897/ERR.9000156

Karaoğlan Yılmaz, F. G., Yılmaz, R., \& Öztürk, T. (2020). Üniversite öğrencilerinin web tabanlı biçimlendirmeye yönelik değerlendirme sistemini kabul durumlarının incelenmesi [Examining university students' acceptance of web-based formative assessment system]. Hacettepe Üniversitesi Eğitim Fakültesi Dergisi, 35(Özel Sayı), 25-36. doi:10.16986/HUJE.2020063671

Kline, P. (1999). The handbook of psychological testing (2nd ed.). London: Routledge.

Maqableh, M., Masa'deh, R., \& Mohammed, A. (2015). The acceptance and use of computer based assessment in higher education. Journal of Software Engineering and Applications, 8(10), 557-574. doi: 10.4236/jsea.2015.810053.

Maphosa, V., Dube, B., \& Jita, T. (2020). A UTAUT evaluation of WhatsApp as a tool for lecture delivery during the COVID-19 lockdown at a Zimbabwean University. International Journal of Higher Education, 9(5), 84-93. doi:10.5430/ijhe.v9n5p84

Okocha, F., Eyiolorunshe, T. A., \& Owolabi, S. (2017). Student perception and acceptance of computer based testing: a case study of Landmark University undergraduate students. Journal of Digital Innovations and Contemporary Research in Science and Engineering, 5(1), 25-32. doi: 10.22624

Rogers, E. M. (1995). Diffusion of innovations (4th ed.). New York: Free Press.

Sarrayrih, M. A., \& Ilyas, M. (2013). Challenges of online exam, performances and problems for online university exam. International Journal of Computer Science Issues (IJCSI), 10(1), 439-443. Retrieved from: http://citeseerx.ist.psu.edu/viewdoc/download?doi=10.1.1.698.304\&rep=rep1\&type =pdf

Schumacker, R. E., \& Lomax, R. G. (2010). A beginner's guide to structural equation modeling (3rd ed.). New York: Routledge.

Sriyeni, Y., Antoni, D., \& Akbar, M. (2018). Analisis penerimaan dan penggunaan teknologi computer based test (cbt) sebagai media ujian online dengan model uified theory of acceptance and use of technology (UTAUT). Jurnal Teknologi dan Informatika, 8(1), 93104. Retrieved

from: http://ojs.palcomtech.ac.id/index.php/teknomatika/article/view/100

Sümer, N. (2000). Yapisal eşitlik modelleri: Temel kavramlar ve örnek uygulamalar [Structural equation modeling: Basic concepts and applications]. Türk Psikoloji Yazılarl, 3(6), 49-74. Retrieved from: http://www.nebisumer.com/wpcontent/uploads/2015/03/SumerN.2000.YEM_TPY.pdf 
Taherdoost, H. (2016). Sampling methods in research methodology; How to choose a sampling technique for research. International Journal of Academic Research in Management (IJARM), 5(2), 18-27.doi: 10.2139/ssrn.3205035

Taherdoost, H. (2019). Importance of technology acceptance assessment for successful implementation and development of new technologies. Global Journal of Engineering Sciences, 1(3), 1-3. Retrieved from: https://ssrn.com/abstract=3313984

Tan, P. J. B. (2013). Students' adoptions and attitudes towards electronic placement tests: A UTAUT analysis. American Journal of Computer Technology and Application, 1(1), 1423. Retrieved from: http://www.ajcta.com/

Terzis, V., \& Economides, A. A. (2011). The acceptance and use of computer based assessment. Computers \& Education, 56(4), 1032-1044. doi: 10.1016/j.compedu.2010.11.017

Terzis, V., Moridis, C. N., Economides, A. A., \& Mendez, G. R. (2013). Computer based assessment acceptance: A cross-cultural study in Greece and Mexico. Journal of Educational Technology \& Society, 16(3), 411-424. Retrieved from: https://www.jstor.org/stable/jeductechsoci.16.3.411

Trochim, W. M. K. (n.d.). Research Methods Knowledge Base. Retrieved from: https://conjointly.com/kb/

Venkatesh, V., Morris, M. G., Davis, G. B., \& Davis, F. D. (2003). User acceptance of information technology: Toward a unified view. MIS Quarterly, 27(3), 425-478. doi: $10.2307 / 30036540$

Zheng, M., \& Bender, D. (2019). Evaluating outcomes of computer-based classroom testing: Student acceptance and impact on learning and exam performance. Medical Teacher, 41(1), 75-82. doi: 10.1080/0142159X.2018.1441984 
The ethics committee approval for this study was obtained from the Ethics Committee of the Rectorate of Ankara University, dated 07/10/2019 and numbered 12/357.

\section{Statement of Contribution of Researchers to the Article:}

1st author contribution rate: $70 \%$

2nd author contribution rate: $30 \%$

\section{Conflict of Interest Statement:}

There is no conflict of interest.

\section{Statement of Financial Support or Acknowledgment:}

No financial support was received from any institution for this study. We want to thank to academic experts, who helped us for survey development and data collection processes. 